\title{
PENDAMPINGAN DESA WISATA DALAM MENINGKATKAN KEPUASAN WISATAWAN PADA ERA NEW NORMAL DI DESA WISATA SANGEH
}

\author{
I Made Bayu Wisnawa ${ }^{1, *)}$, Sulistiyo Adi Joko Saharjo ${ }^{2)}$, Anak Agung Ratih \\ Wijayanti $^{3)}$, Ni Nyoman Nidya Trianingrum ${ }^{4}$, , Ni Wayan Mekarini5), I Made \\ Hedy Wartana ${ }^{\text {) }}$ \\ (Universitas Triatma Mulya $\mathbf{1}^{\mathbf{1 , 2 , 3 , 4 , 5 , 6} \text { ) }}$ \\ bayu.wisnawa@triatmamulya.ac.id ${ }^{*}$
}

\begin{abstract}
The Covid-19 pandemic poses a threat as well as an opportunity for tourist villages. Losing tourists is a threat, while improvement to prepare quality tourism is an opportunity. The problems faced by Sangeh Tourism Village are : i) there were still many people who had not implemented health protocols, ii) the potential for village tourism had not been fully offered in tour packages. The mentoring activity for Sangeh Tourism Village aims to increase tourist satisfaction in the normal era. The method used by giving lectures and discussions. The results of the activity show: $i)$ increased public awareness regarding the application of health protocols, ii) the formation of natural, cultural and artificial tourism packages.
\end{abstract}

Keywords: assistance, tourism village, covid-19.

\section{PENDAHULUAN}

Desa Wisata Sangeh berada di Desa Sangeh, Kecamatan Abian Semal, Kabupaten Badung, Bali. Lokasi desa sangat strategis berada di antara Bedugul (Tabanan), Kintamani (Bangli), Kuta (Badung) dan Ubud (Gianyar) yang merupakan jalur emas wisata di Bali. Desa Wisata Sangeh selalu dilalui oleh wisatawan yang melakukan perjalanan wisata dari Bali Selatan ke Bali Tengah. Sampai dengan saat ini kurang lebih 6.000 wisatawan perhari yang singgah dan melewati Desa Sangeh. Desa Wisata Sangeh memiliki atraksi wisata alam seperti hutan Alas Pala dan pemandangan persawahan; wisata budaya seperti Pura Taman Mumbul, serta berbagai fasilitas penunjang sebagai kawasan tujuan wisata (Wisnawa et al., 2020). Semua persyaratan desa wisata sudah terpenuhi Desa Sangeh, sehingga pemberdayaan masyarakat akan lebih luas dan cepat karena potensi desanya sudah ada.

Desa Wisata Sangeh menerapkan Sapta Pesona untuk meningkatkan kepuasan wisatawan. Sapta Pesona merupakan program pemerintah yang sudah terbukti berhasil dalam mengembangkan kepariwisataan di Indonesia (Wisnawa et al., 2019). Sapta Pesona, yang terdiri dari: aman,tertib, bersih, sejuk, indah, ramah dan kenangan. Namun demikian, dalam kondisi Pandemi Covid-19, kondisi rasa aman masih sulit diwujudkan di Desa Wisata Sangeh. Semenjak Pandemi Covid-19 pada Maret 2020, tingkat kunjungan wisatawan ke Desa Wisata Sangeh mengalami penurunan yang sangat berarti. Keadaan ini disikapi oleh 
(I Made Bayu Wisnawa ${ }^{1)}$, Sulistiyo Adi Joko Saharjo ${ }^{2}$, Anak Agung Ratih Wijayanti ${ }^{3)}$, Ni Nyoman Nidya Trianingrum ${ }^{4)}$, Ni Wayan Mekarini ${ }^{5)}$, I Made Hedy Wartana ${ }^{6)}$ )

\begin{abstract}
pemerintah untuk memberikan bantuan sarana dan prasarana penerapan protokol kesehatan. Bantuan tersebut diberikan di kantor desa, Hutan Alas Pala (Sangeh Monkey Forest) dan Pura Taman Mumbul. Pemerintah sudah melakukan sosialisasi mengenai protokol kesehatan melalui media massa, media sosial dan penyuluhan kepada masyarakat. Namun berdasarkan wawancara dan pengamatan, cukup banyak masyarakat yang belum sepenuhnya menerapkan protokol tersebut. Masih ada yang enggan menggunakan masker atau menggunakan masker tapi dengan cara yang tidak benar. Masih

akses, amenitis, ancelery dan keterlibatan masyarakat. Dari sisi atraksi, masih banyak potensi wisata Desa Sangeh yang belum dapat dikelola dengan baik untuk ditawarkan sebagai paket produk wisata.

Berdasarkan uraian di atas, maka terdapat beberapa kelemahan yang dimiliki Desa Wisata Sangeh, yakni : (i) belum segenap masyarakat menerapkan standar protokol Covid19, dan (ii) belum memiliki paketpaket wisata yang mampu memanfaatkan potensi wisata Desa Sangeh . Oleh karena itu kegiatan pendampingan desa wisata kali ini bertujuan untuk mengatasi kelemahan tersebut.
\end{abstract} ada yang meragukan bahaya virus Covid-19 dan menganggap sebagai penyakit flu biasa saja.

Selain rasa aman yang, masih ada unsur Sapta Pesona lainnya yang masih belum dapat dipenuhi yakni 'kenangan'. Desa Wisata Sangeh belum memiliki cinderamata khas yang dapat ditawarkan kepada wisatawan yang berkunjung. Terwujudnya kepuasan wisatawan tidak terlepas dari keutuhan Desa Wisata Sangeh sebagai sebuah daya tarik wisata (Wisnawa et al., 2019) dimana terpenuhinya unsur atraksi,

\section{METODE PELAKSANAAN}

Tahapan-tahapan yang digunakan untuk menyelesaikan permasalahan tersebut adalah dengan melakukan pendampingan desa wisata. Kegiatan ini sepenuhnya didukung oleh Kementrian Pariwisata Ekonomi Kreatif.

Model dan Desain Pelaksanaan Program Pendampingan

Model, desain pelaksanaan program pendampingan seperti pada Gambar 1 


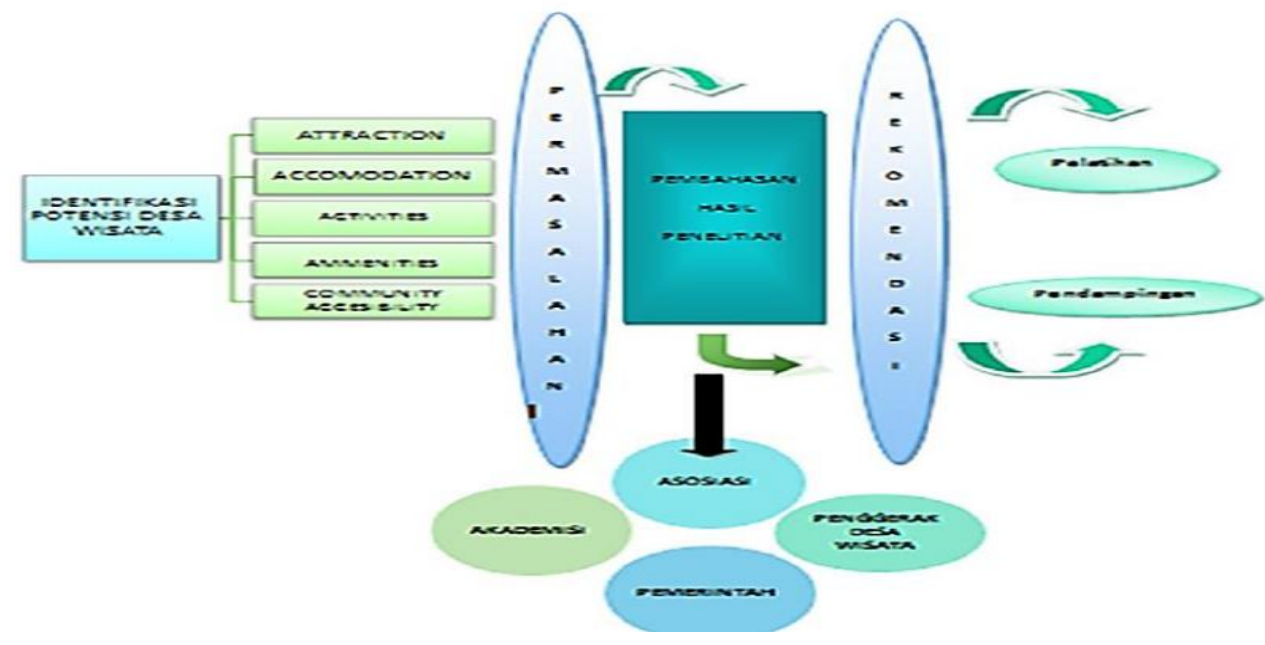

Gambar 1

Model, Desain Pelaksanaan Program Pendampingan Desa Wisata Sangeh Kerjasama Kemenparekraf RI dengan STIPAR Triatma Jaya

Sebelum melakukan kegiatan pelatihan dan pendampingan, dilakukan identifikasi potensi desa wisata yang meliputi atraksi, akomodasi, aktifitas wisata, amenities dan community accessibility(Sari \& Widiyastuti, 2020). Selanjutnya dirumuskan permasalahan yang dihadapi dalam pengembangan Desa Wisata Sangeh. Permasalahan tersebut ditindak lanjuti dengan melakukan penelitian. Hasil analisis dan pembahasan pada penelitian dengan melibatkan stakeholder pariwisata(Wisnawa et al., 2021) memunculkan simpulan dan rekomendasi untuk melakukan kegiatan pendampingan dan pelatihan.

Kegiatan tersebut tidak berjalan sesuai dengan perencanaan karena Pandemik Covid-19 yang sangat membatasi mobilitas masyarakat. Meskipun demikian kegiatan ini pada akhirnya dapat berjalan dengan baik walaupun tidak optimal.

1. Identifikasi potensi desa wisata. Identifikasi potensi Desa Wisata Sangeh meliputi : a. Atraksi Atraksi yang dimiliki Desa Wisata Sangeh meliputi, atraksi wisata alam, dan wisata budaya. Atraksi wisata alam meliputi : pemandangan sawah, Hutan Pala (Monkey Forest), Tempat Penglukatan Pancoran Solas (Taman Mumbul)

b. Akomodasi Desa Wisata Sangeh sudah memiliki fasilitas akomodasi berupa homestay yang dikelola oleh swasta, antara lain : Kafein House Sangeh, Sangeh Uma Dong Loka Villa, Made Miasa Bed and Breakfast, Bali Firefly BNB.

c. Aktifitas wisata Aktifitas wisata yang dilakukan di Desa Wisata Sangeh antara lain : Yoga di Pura Taman Mumbul Pancoran Solas, Rekreasi melihat pemandangan dan memberi makan ikan di Pura Taman Mumbul Pancoran Solas, Melukat / meruwat (membersihkan badan halus) di Pura Taman Mumbul Pancoran Solas, Pura Taman Mumbul 
Pancoran Solas juga memiliki wantilan yang dapat digunakan untuk berkumpul bersama keluarga tanpa dibebankan biaya tambahan, Wisata kuliner berupa masakan khas Bali seperti lawar kuwir, lawar kebo, lawar Babi, Sate Babi, Sate Ikan, yang berada disepanjang jalan antara Hutan Pala (Monkey Forest) dengan Pura Taman Mumbul Pancoran Solas, Wisata alam melihat pura dan hutan pala dan monyet di Hutan Pala (Sangeh Monkey Forest), Joging dan Tracking disekitar Desa Wisata Sangeh, Cycling, Aktifitas fotograpi dan Droning.

d. Amenities atau fasilitas yang dimiliki Desa Wisata Sangeh sudah memadai, meliputi : akomodasi, tempat makan dan minum, toilet, tempat parkir, internet, dan air bersih.

e. Community accesibility Akses masuk ke Desa Wisata Sangeh sudah sangat bagus, dengan jalan utama lebar 8 s.d 10 meter, bahkan untuk masuk ke tempat terpencil sudah dipaving dan di semen.

2. Permasalahan yang dihadapi

Permasalahan yang dihadapi saat ini antara lain :

a. Pengetahuan masyarakat mengenai penerapan Protokol Kesehatan terkait Pandemik Covid-19 masih belum merata.

b. Belum memiliki paket wisata yang dapat menawarkan segenap potensi wisata Desa Sangeh.
3. Penelitian.

Penelitian dilakukan dengan melakukan observasi dan wawancara kepada aparat desa, pokdarwis dan masyarakat. Hasil penelitian menunjukkan bahwa :

a. Masih terdapat perbedaan persepsi masyarakat mengenai situasi Pandemik Covid-19. Pada obyek wisata sudah melengkapi diri dengan alat pelindung diri, mulai dari tempat cuci tangan, alat pengecekan suhu tubuh, hand sanitizer, masker bahkan pihak kepolisian secara rutin melakukan pemeriksaan namun masih ada sebagian masyarakat yang tidak menerapkannya dengan benar. Hal ini disebabkan kurangnya sosialisasi dan edukasi mengenai Pandemik Covid-19.

b. Desa Wisata Sangeh belum memiliki paket wisata yang mampu menawarkan segenap potensi wisata yang dmiliki Desa Sangeh. Hal tersebut menyebabkan kekurang sempurnaan layanan wisata bagi wisatawan. Dengan melihat branding Desa Wisata Sangeh yang sudah dikenal berbagai kelompok wisatawan, tentunya hal ini cukup memprihatinkan. Padahal cukup banyak potensi yang dapat dikelola, misalnya produk kuliner berupa lawar, sate; kemudian buah kelapa yang dapat dikelola menjadi minyak goreng atau Virgin Coconut Oil, dan buah pala yang dapat dikelola menjadi lulur yang berkhasiat bagi kulit; demikian pula citra "monkey forest" dan Pura Taman Mumbul Pancoran Solas yang dapat 
diabadikan menjadi baju kaos, gantungan kunci dan aneka gimmick lainnya.

4. Rekomendasi kegiatan pelatihan dan pendampingan.

Berdasarkan identifikasi potensi wisata, permasalahan dan penelitian yang dilakukan, maka rekomendasi kegiatan pelatihan dan pendampingan yang dilakukan sebagai berikut : a. Sadar Wisata dan New Normal dengan materi : CHSE (Cleanliness, Health, Safety, Environment), Sapta Pesona dan Pelayanan Prima

b. Pengembangan Potensi Produk Pariwisata, dengan materi : Exploring, Packaging dan Presentation

\section{Roadmap Pelaksanaan Program Pendampingan}

\begin{tabular}{|c|l|}
\hline Feb & $\begin{array}{l}\text {-Pra Survey } \\
\text { - Survey lanjutan }\end{array}$ \\
\hline Feb & $\begin{array}{l}\text { - Analisis data } \\
\text { - Presentasi hasil kajian dan rekomendasi }\end{array}$ \\
\hline Juli & \begin{tabular}{l} 
- $\begin{array}{c}\text { - Revosiasi proposal } \\
\text { Agustus }\end{array}$ \\
-Sosialisasi \\
\hline -Pelatihan tidak dapad dilakukan karena Pandemik Covid-19
\end{tabular} \\
\hline September & - Pendampingan \\
\hline Oktober & - Pelaporan dan Presentasi \\
\hline
\end{tabular}

Gambar 2

\section{Roadmap Pelaksanaan Program Pendampingan Desa Wisata Sangeh} Kerjasama Kemenparekraf RI dengan STIPAR Triatma Jaya Tahun 2020

Pada Gambar 2 dapat dilihat bahwa awal kegiatan pendampingan dimulai dengan undangan kerjasama pendampingan desa wisata oleh Kemenparekraf RI di awal tahun 2020. Kerjasama ini merupakan lanjutan dari kegiatan pendampingan yang dilakukan pada tahun 2019, di mana sudah melakukan kegiatan (i) peningkatan kemampuan ranger/ guide lokal pada bidang kemampuan berbahasa Inggris dan teknik kepemanduan, (ii) peningkatan tata kelola homestay, (iii) peningkatan kempuan memasak (food production) dan (iv) peningkatan kemampuan menyajikan makanan (food and beverage service). Kegiatan tersebut dilakukan sebanyak dua kali dalam tahun 2019 dengan total peserta 50 yang berasal dari Pokdarwis, tokoh masyarakat dan masyarakat umum.

Pada bulan Januari 2020, STIPAR Triatma Jaya mendapatkan kabar gembira untuk terlibat bersama Kemenparekraf RI dalam melanjutkan kegiatan pendampingan desa wisata. Hal tersebut ditindaklanjuti LPPM STIPAR Triatma Jaya dengan melakukan rapat kordinasi dengan team TOT (Train of Trainer) STIPAR Triatma Jaya dalam menentukan desa 
wisata dan program yang akan diterapkan. Hasil rapat memutuskan melanjutkan Desa Sangeh sebagai desa wisata yang didampingi. Selanjutnya LPPM STIPAR Triatma Jaya menghubungi Kepala Desa Sangeh dan menghasilkan persetujuan kerjasama pendampingan Desa Wisata Sangeh

Pada awal bulan Februari 2020, dilakukan pra survey dan survey lanjutan mengenai potensi Desa Wisata Sangeh, analisis data dan presentasi hasil kajian dan rekomendasi. Adapun program yang direncanakan untuk dilaksanakan pada saat itu antara lain : (i) pengembangan produk cinderamata dan (ii) peningkatan kemampuan guide lokal.

Pada pertengahan bulan ini juga dilakukan sosialiasi program pendampingan oleh Kemenparekraf RI dengan STIPAR Triatma Jaya dan perguruan tinggi lainnya di Hotel Grand Mega Denpasar. Selanjutnya Kemenparekraf RI bersama STIPAR Triatma Jaya menandatangi Memorandum of Understanding di Jakarta. Pada bulan Maret sampai dengan Juni 2020, proses persiapan pendampingan vakum yang disebabkan Pandemik Covid-19. Kebijakan pemerintah untuk melaksanakan Work from Home (WFH) membatasi gerak kordinasi, disamping itu penyesuian segenap civitas akademika dalam menerapkan protokol Covid-19 dan penggunaan soft ware Google Class Room, Zoom,
Webex dalam kegiatan Tri Dharma Perguruan Tinggi cukup menyita perhatian. Pada bulan Juli 2020, STIPAR Triatma Jaya mengirim dosen untuk mengikuti kegiatan TOT (Train of Trainer) Pendampingan Desa Wisata yang diselenggarakan oleh Kemenparekraf RI di Hotel Grand Hilton Tuban Bali. Materi yang diberikan pada saat TOT juga disosialisasikan kepada segenap civitas akademika STIPAR Triatma Jaya. Kegiatan lainnya pada bulan ini adalah pengiriman revisi proposal pendampingan desa wisata ke Kemenparekraf RI. Pada bulan Agustus 2020, dilakukan kordinasi pelaksanaan pendampingan dengan Desa Wisata Sangeh, pada awalnya ditetapkan tanggal 18 Agustus 2020, dan mengalami beberapa kali perubahan, terkait penyesuaian waktu dengan Kemenparekraf RI di masa pandemik Covid 19 ini. Keputusan terakhir dari Kemenparekraf RI kegiatan pendampingan dilakukan di Hotel Element by Westin Ubud pada Kamis, 3 September 2020. Selanjutnya pada bulan Oktober 2020, pelaporan kegiatan pendampingan desa wisata ini dilakukan.

\section{HASIL DAN PEMBAHASAN \\ Profil Peserta Pelatihan dan Pendampingan}

Profil peserta pendampingan seperti pada Tabel 1 berikut 
SAVE: Synergy and Society Service

Vol 1, No 2, Desember 2021 hal. 56 - 66

(I Made Bayu Wisnawa ${ }^{1)}$, Sulistiyo Adi Joko Saharjo ${ }^{2}$, Anak Agung Ratih Wijayanti ${ }^{3)}, \mathrm{Ni}$ Nyoman Nidya Trianingrum ${ }^{4)}$, Ni Wayan Mekarini ${ }^{5)}$, I Made Hedy Wartana ${ }^{6)}$ )

Tabel 1

Profil Peserta Pelatihan dan Pendampingan Desa Wisata Sangeh 2020

\begin{tabular}{|l|l|l|l|c|}
\hline NO & NAMA PESERTA & L/P & ALAMAT & USIA \\
\hline 1 & I Putu Krishna Dana & L & Br Sibang Sangeh & 25 \\
\hline 2 & Ida Bagus Tirtayasa & L & Br Brahmana Sangeh & 42 \\
\hline 3 & Putu Dirga Yusa & L & Sangeh & 27 \\
\hline 4 & I Wayan Wiastra & L & Br Pacung Sangeh & 22 \\
\hline 5 & I Nyoman Gede Triadi Mahendra & L & Br Tegal Gerana Sangeh & 27 \\
\hline 6 & I Wayan Agus Widiartha & L & Br Tegal Gerana Sangeh & 28 \\
\hline 7 & Putu Arsa Janitra & L & Sangeh & 25 \\
\hline 8 & I Made Mohon & L & Sangeh & 50 \\
\hline 9 & I Kadek Maindra & L & Br Batulumbang Gerana Sangeh & 26 \\
\hline 10 & Km Bayu Ambara Putra & L & Br Tegal Gerana Sangeh & 25 \\
\hline 11 & I Putu Diva Pramadana & L & Br Batulumbang Gerana Sangeh & 25 \\
\hline 12 & I Made Adnyana & L & Sangeh & 24 \\
\hline 13 & Ida Bagus Suamba & L & Sangeh & 23 \\
\hline 14 & I Wayan Putra Astara & L & Br Tegal Gerana Sangeh & 22 \\
\hline 15 & Ida Bagus Ketut Darmika & L & Sangeh & 27 \\
\hline 16 & I Kadek Surya Pranata & L & Sangeh & 28 \\
\hline 17 & I Wayan Sutama Yasa & L & Br Muluk Babi Sangeh & 32 \\
\hline 18 & Kadek Agus Wirawan & L & Br Pacung Sangeh & 35 \\
\hline 19 & I Nyoman Rasna & L & Sangeh & 34 \\
\hline 20 & NiPutu Dwi Maharani & P & Br Tegal Gerana Sangeh & 19 \\
\hline
\end{tabular}

Sumber : Dokumentasi Panitia STIPAR TJ, 2020

Berdasarkan usia, sebagian peserta berusia di antara 20 s.d 30 tahun (sebanyak 15 orang atau $75,00 \%)$, di atas 30 tahun sebanyak 4 orang $(20,00 \%)$, dan kurang dari 20 tahun sebanyak 1 orang $(5,00 \%)$. Tingkat pendidikan SMA sebanyak 15 orang $(95,00 \%)$ dan sarjana sebanyak 5 orang $(5,00 \%)$. Sebagian besar sudah bekerja pada sektor pariwisata, di luar Desa Sangeh.

\section{Pelaksanaan Pelatihan dan Pendampingan}

Pelaksanaan pelatihan dan pendampingan seperti pada Tabel 2 berikut

Tabel 2

Pelaksanaan Pelatihan dan Pendampingan Desa Wisata Sangeh 2020

\begin{tabular}{|l|l|l|l|l|l|}
\hline No & Waktu & Kegiatan & Materi & Metode & Peran Masyarakat \\
\hline 1 & $\begin{array}{l}08.00 \text { s.d } \\
11.00\end{array}$ & $\begin{array}{l}\text { Sadar Wisata dan } \\
\text { New Normal }\end{array}$ & $\begin{array}{l}\text { CHSE, Sapta } \\
\text { Pesona dan } \\
\text { Pelayanan Prima }\end{array}$ & $\begin{array}{l}\text { Ceramah dan } \\
\text { Diskusi }\end{array}$ & $\begin{array}{l}\text { Aktif dalam } \\
\text { mendengarkan dan } \\
\text { diskusi }\end{array}$ \\
\hline 2 & $\begin{array}{l}11.00 \text { s.d } \\
17.00\end{array}$ & $\begin{array}{l}\text { Pengembangan } \\
\text { Potensi Produk } \\
\text { Wisata }\end{array}$ & $\begin{array}{l}\text { Exploring, } \\
\text { Packaging dan } \\
\text { Presentation }\end{array}$ & $\begin{array}{l}\text { Ceramah, Diskusi } \\
\text { dan Focus Group } \\
\text { Discusion }\end{array}$ & $\begin{array}{l}\text { Aktif dalam } \\
\text { mendengarkan, } \\
\text { presentasi dan } \\
\text { diskusi }\end{array}$ \\
\hline
\end{tabular}

Sumber : Dokumentasi Panitia STIPAR TJ, 2020

Pelaksanaan pelatihan dan pendampingan Desa Wisata Sangeh 2020 dilakukan selama satu hari yakni pada hari Kamis, 3 September 2020 yang dimulai pukul 08.00 s.d 17.00 wita. Ada dua kegiatan utama, yaitu : i) Sadar wisata dan New Normal, dan ii) Pengembangan potensi produk 
wisata. Kegiatan ini di moderatori oleh Dr. I Made Bayu Wisnawa.,A.Par.,M.M.,M.Par.

Sebelum kegiatan peserta diberikan Pre-Test, dan setelah kegiatan diberikan Post-Test. Pada kegiatan sadar wisata dan new normal terdapat tiga materi yang diberikan, yakni : i) CHSE (Cleanliness, Health, Safety dan Environment), ii) Sapta Pesona dan iii) Pelayanan prima yang diberikan oleh nara sumber $\mathrm{Ni}$ Nyoman Nidya Trianingrum.,S.Pd.,M.Pd sebagai pemateri utama, dan Dr.Dra. Ni Wayan Mekarini.,M.Hum sebagai pemateri pendukung. Metode yang digunakan adalah metode ceramah dan diskusi.

Pada kegiatan pengembangan potensi produk wisata terdapat tiga materi yang diberikan, yakni : i) Exploring, ii) Packaging dan iii) Presentation yang diberikan oleh nara sumber Dr.Dra. Ni Wayan Mekarini.,M.Hum, sebagai pemateri utama, dan Ni Nyoman Nidya Trianingrum S,Pd.,M.Pd sebagai pemateri pendukung. Metode yang digunakan adalah metode ceramah, diskusi dan Focus Group Discussion. 4.3 Pembahasan Hasil Pelatihan dan Pendampingan Hasil pelatihan dan pendampingan dapat dilihat dari : i) Hasil Pre-test dan Post-test, ii) Perencanaan produk wisata, seperti pada paparan berikut :

1. Hasil Pre-test dan Post-test Hasil Pre-test dan Post-test dapat dilihat pada Tabel 3 berikut

Tabel 3

Pelaksanaan Pelatihan dan Pendampingan Desa Wisata Sangeh 2020

\begin{tabular}{|c|c|c|c|c|c|}
\hline \multirow{2}{*}{ No } & JAWABAN BENAR & $\mathbf{\%}$ & JAWABAN BENAR & $\%$ & $\%$ \\
\cline { 2 - 6 } & PRESTEST & PRETEST & POSTEST & POSTEST & KEMAJUAN \\
\hline 1 & 19 & 76 & 23 & 92 & 16 \\
\hline 2 & 19 & 76 & 21 & 84 & 8 \\
\hline 3 & 17 & 68 & 23 & 92 & 24 \\
\hline 4 & 21 & 84 & 23 & 92 & 8 \\
\hline 5 & 16 & 64 & 23 & 92 & 28 \\
\hline 6 & 15 & 60 & 20 & 80 & 20 \\
\hline 7 & 20 & 80 & 23 & 92 & 12 \\
\hline 8 & 22 & 88 & 25 & 100 & 12 \\
\hline 9 & 14 & 56 & 22 & 88 & 32 \\
\hline 10 & 23 & 92 & 25 & 100 & 8 \\
\hline 11 & 19 & 76 & 23 & 92 & 16 \\
\hline 12 & 19 & 76 & 21 & 84 & 8 \\
\hline 13 & 20 & 80 & 24 & 96 & 16 \\
\hline 14 & 17 & 68 & 22 & 88 & 20 \\
\hline 15 & 18 & 72 & 20 & 80 & 8 \\
\hline 16 & 24 & 96 & 25 & 100 & 4 \\
\hline 17 & 20 & 80 & 22 & 88 & 8 \\
\hline 18 & 21 & 84 & 23 & 92 & 8 \\
\hline 19 & 12 & 48 & 20 & 80 & 32 \\
\hline 20 & 20 & 80 & 22 & 88 & 8 \\
\hline & Rata-rata & 75,2 & Rata-rata & 90 & 14,8 \\
\hline
\end{tabular}

Sumber : Dokumentasi Panitia STIPAR TJ, 2020 
Pertanyaan yang diberikan pada pre-test dan post-test mengacu pada keseluruhan materi yang diberikan pada kegiatan pelatihan dan pendampingan. Hasil pre-test menunjukkan nilai rata-rata sebesar 75,20 yang menunjukkan bahwa peserta pada umumnya memiliki bekal pemahaman yang baik pada saat sebelum mengikuti kegiatan. Hal ini disebabkan sebagian besar peserta berpendidikan rata-rata SMA dan memiliki pengalaman bekerja pada sektor pariwisata, hal ini juga didukung kegiatan pelatihan dan pendampingan sebelumnya yakni pada tahun 2019, ditambah berbagai kegiatan pelatihan dan pendampingan lainnya yang dilakukan oleh akademisi, pemerintah dan praktisi pada kesempatan sebelumnya.

Rata-rata hasil post-test sebesar 90,00 yang menunjukkan peningkatan sebesar 14,80 poin dari hasil pre-test. Hal ini menunjukkan bahwa tingkat pemahaman peserta terhadap materi pelatihan dan pendampingan yang diberikan pada tingkat sangat baik. Oleh karena itu dapat dikatakan bahwa kegiatan pelatihan dan pendampingan ini berhasil meningkatkan pengetahuan peserta pada bidang: i) sadar wisata dan new normal, ii) perencanaan produk wisata.

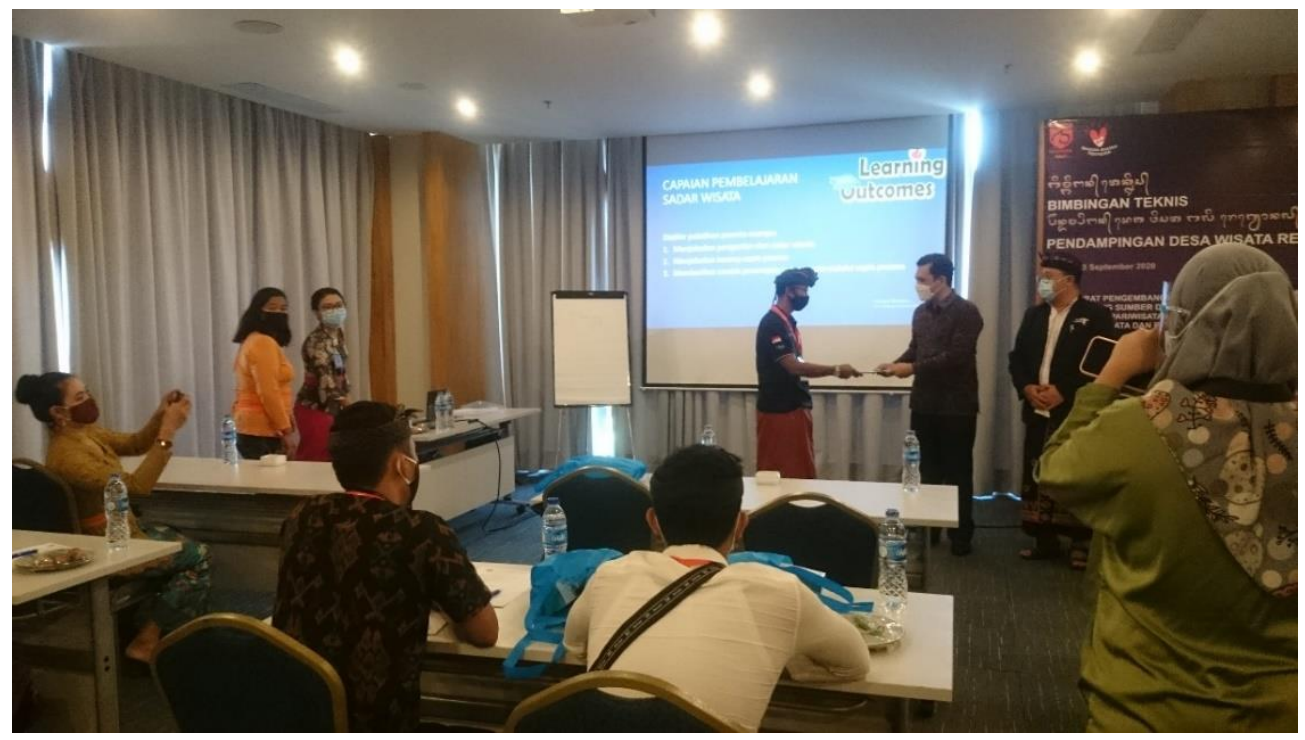

Gambar 3

Pembukaan Kegiatan Pendampingan Desa Wisata

Sumber : LPPM STIPAR Triatma Jaya. 2020

\section{Perencanaan produk wisata}

Keterampilan peserta dalam merencanakan produk wisata diasah melalui kegiatan focus group discussion yang dibagi menjadi empat kelompok dengan hasil sebagai berikut: a. Paket produk wisata alam Paket produk wisata alam direncanakan minimal wisatawan menginap satu malam di salah satu rumah milik penduduk lokal atau home stay yang ada di wilayah Desa Sangeh. Kegiatan yang dilakukan antara 
lain : tracking, cycling, menikmati keindahan tumbuh-tumbuhan yang ada di Alas Pala, menikmati keindahan dan kesegaran area persawahan serta perkebunan. Pemilihan rute melewati Hutan Alas Pala (monkey forest), dan Pura Taman Mumbul Pancoran Solas.

b. Paket produk wisata budaya Paket produk wisata budaya direncanakan minimal wisatawan menginap satu malam di salah satu rumah milik penduduk lokal atau home stay yang ada di wilayah Desa Sangeh. Kegiatan yang dilakukan antara lain : melakukan penglukatan/ mandi suci di Pura Taman Mumbul Pancoran Solas, menikmati keindahan dan sejarah Hutan Alas Pala (monkey forest) yang dipandu ranger. Guide lokal, serta melihat replika rumah tua Bali yang terbuat dari batu merah dan dedak padi di Pondok Jaka. Pemilihan rute juga melewati Hutan Alas Pala (monkey forest), dan Pura Taman Mumbul Pancoran Solas.

c. Paket produk wisata alam dan budaya. Paket produk ini merupakan gabungan dari produk wisata alam dan budaya dengan lama tinggal wisatawan selama tiga hari dua malam pada rumah penduduk lokal atau home stay yang ada di Desa Sangeh.

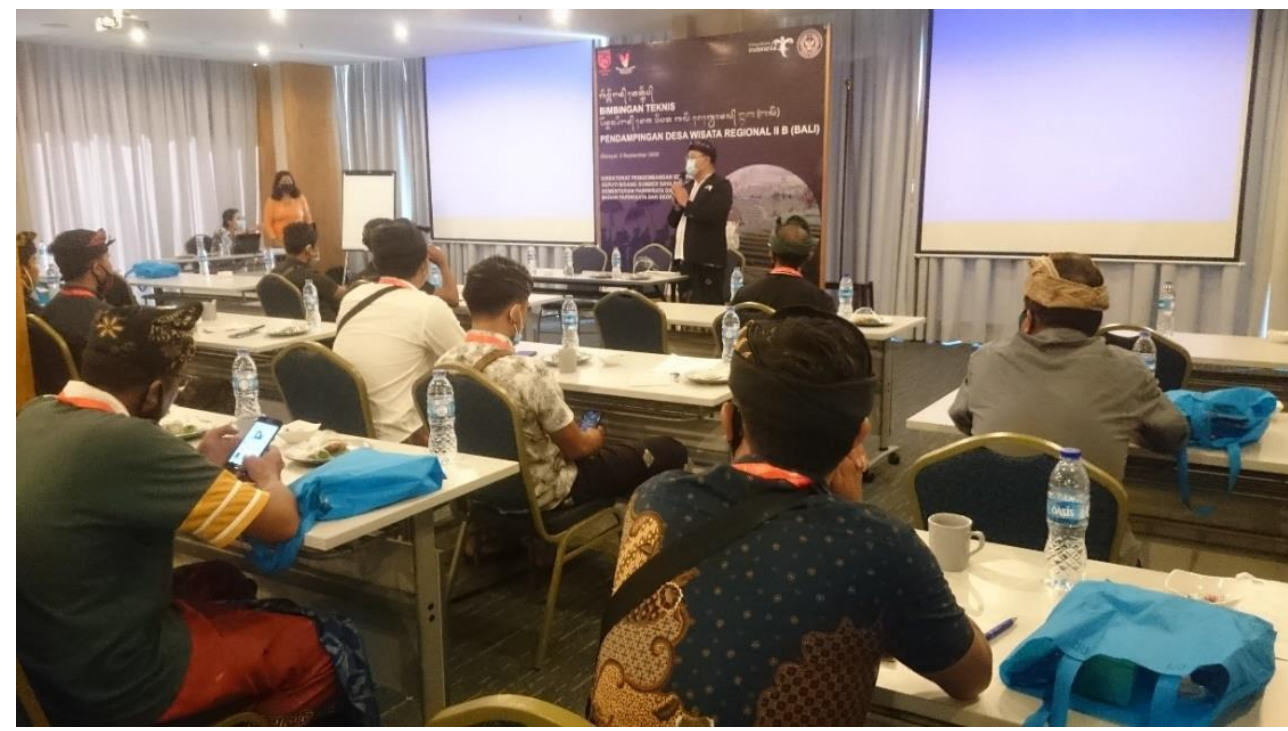

Gambar 4

Kegiatan Pendampingan Desa Wisata

Sumber : LPPM STIPAR Triatma Jaya. 2020

\section{KESIMPULAN}

Berdasarkan uraian yang disampaikan pada bagian sebelumnya, maka kegiatan Pelatihan dan Pendampingan Desa Wisata Sangeh Kerjasama STIPAR Triatma Jaya dengan Kemenparekraf RI dapat disimpulkan sebagai berikut :

1. Secara umum kegiatan sudah terlaksana dengan baik, yang dapat dibuktikan dengan peningkatan pemahaman peserta terhadap 
(I Made Bayu Wisnawa $^{1)}$, Sulistiyo Adi Joko Saharjo ${ }^{2}$, Anak Agung Ratih Wijayanti ${ }^{3)}$, Ni Nyoman Nidya Trianingrum ${ }^{4)}$, Ni Wayan Mekarini ${ }^{5)}$, I Made Hedy Wartana ${ }^{6)}$ )

materi yang diberikan, bahkan peserta sudah mampu merencanakan paket produk wisata dengan baik.

2. Pandemik Covid-19 menyebabkan cukup banyak perubahan dan penyesuaian dalam pelaksanaan kegiatan ini.

Berdasarkan masukan dari masyarakat Desa Wisata Sangeh dan civitas akademika STIPAR Triatma Jaya, maka saran yang diberikan terhadap kegiatan ini adalah sebagai berikut :

1. Semoga kegiatan pendampingan desa wisata ini dapat dilanjutkan pada tahun 2021.

2. Semoga jumlah desa yang diberi kesempatan untuk dibina tidak hanya desa yang berstatus desa wisata, tetapi desa-desa lainnya yang memiliki potensi yang layak untuk dikembangkan.

\section{UCAPAN TERIMA KASIH}

Ucapan terimakasih kepada Kementrian Pariwisata dan Ekonomi Kreatif Republik Indonesia (Kemenparekraf RI) dan Kepala Desa Sangeh, yang memberikan kesempatan kepada STIPAR Triatma Jaya untuk mengabdikan dirinya kepada masyarakat Desa Sangeh.

\section{DAFTAR PUSTAKA}

Sari, E. L. P., \& Widiyastuti, D. (2020). Peran Masyarakat Dalam Pengembangan Kampung Wisata Rejowinangun Kotagede Yogyakarta. Jurnal Bumi Indonesia, 9(1), 1-10. http://lib.geo.ugm.ac.id/ojs/inde x.php/jbi/article/view/1153

Wisnawa, I. M. B., Prayogi, P. A., \& Sutapa. (2021). Manajemen
Pemasaran
Pariwisata-
Pengembangan Potensi Produk
Wisata Perdesaan (A. Y. Wati (ed.); First). Deepublish. https://books.google.co.id/book s/about/Manajemen_Pemasaran _Pariwisata_Pengemban.html?i d=ezcgEAAAQBAJ\&redir_esc $=\mathrm{y}$

Wisnawa, I. M. B., Sutapa, I. K., \& Prayogi, P. A. (2020). PERSEPSI WISATAWAN BALI TERHADAP SAPTA PESONA, SUSTAINABILITY DAN KEPUASAN BERWISATA DI THAILAND. Jurnal Perhotelan Dan Pariwisata, 10(1), 47-66. http://triatmajaya.ejurnal.info/in dex.php/triatmajaya/article/view $/ 131 / 35$

Wisnawa, I. M. B., Wijayanti, A. A. R., \& Jokosaharjo, S. (2019). Tourists Expectation and Perception Toward Sangeh Tourism Village. Journal of Business on Hospitality and Tourism, 5(2), 218. https://doi.org/10.22334/jbhost. v5i2.158 